\title{
Strategi Word of Mouth Produk Sinom-Vac: Pembicara, Topik, Alat, Partisipasi dan Pengawasan
}

\author{
Kevin Reynaldi Bagaskara1, Leonard Adrie Manafe², Viviana Sulistya Angraini³, Mayrine \\ Christiyah Nugrahini ${ }^{4}$
}

1,2,3,4 Sekolah Tinggi Ilmu Ekonomi Mahardhika Surabaya

\begin{tabular}{|c|c|}
\hline INFO ARTIKEL & Abstract \\
\hline $\begin{array}{l}\text { Sejarah Artikel: } \\
\text { Diterima } \\
\text { Diperbaiki } \\
\text { Disetujui } \\
\text { Keywords: } \\
\text { Tools; Taking Part; Talkers; } \\
\text { Tracking; Topic; Word of Mouth. }\end{array}$ & $\begin{array}{l}\text { This research was conducted regarding the application of Word of Mouth } \\
\text { which is part of the marketing strategy of Sinom-Vac products. WOM has } \\
\text { elements known as 5Ts (Talkers, Topics, Tools, Taking Part, and Tracking). } \\
\text { The research method uses a descriptive approach involving } 31 \text { informants. } \\
\text { Data collection techniques through questionnaires, direct interviews and photo } \\
\text { documentation. The result of the research shows that the talkers is a consumer } \\
\text { of Sinom-Vac itself. The topic relates to an additional understanding of a } \\
\text { product for consumers, which ends where the informant will conduct product- } \\
\text { related talks with his partners. Testers are given as Tools to prove the quality } \\
\text { of the products offered, after providing excellent service, they are directly or } \\
\text { indirectly part of the Taking Part, and the next step is to enter the Tracking } \\
\text { party stage. Sinom-Vac responds with customer complaints quickly to reduce } \\
\text { negative WOM }\end{array}$ \\
\hline & $x^{2}$ \\
\hline $\begin{array}{l}\text { Kata Kunci: } \\
\text { Alat; Partisipasi; Pembicara; } \\
\text { Pengawasan; Topik; Word of } \\
\text { Mouth. } \\
\text { DOI: }\end{array}$ & $\begin{array}{l}\text { Penelitian ini dilakukan terkait penerapan Word of Mouth yang } \\
\text { merupakan bagian dari strategi pemasaran produk Sinom-Vac. WOM } \\
\text { memiliki elemen yang dikenal dengan } 5 \mathrm{~T} \text { (Pembicara, Topik, Alat, } \\
\text { Partisipasi, dan Pengawasan). Metode penelitian menggunakan } \\
\text { pendekatan kualitatif deskriptif dengan melibatkan } 31 \text { informan. } \\
\text { Teknik pengumpulan data melalui penyebaran kuesioner, wawancara } \\
\text { langsung dilapangan serta dokumentasi foto. Hasil penelitian } \\
\text { menunjukan Talker yang merupakan konsumen Sinom-Vac sendiri. } \\
\text { Topic berhubungan dengan tambahan pemahaman akan suatu produk } \\
\text { untuk para konsumen, yang berakhir dimana informan akan } \\
\text { melakukan pembicaraan kembali terkait produk kepada partnernya. } \\
\text { Diberikannya tester sebagai Tools untuk pembuktian kualitas produk } \\
\text { yang ditawarkan, setelah itu pemberian pelayanan kunjungan yang } \\
\text { prima dilakukan secara langsung atau tidak langsung merupakan } \\
\text { bagian dari Taking Part, dan langkah berikutnya masuk dalam tahap } \\
\text { Tracking pihak Sinom-Vac memberikan respon dengan membalas } \\
\text { keluhan pelanggan dengan cepat untuk mengurangi WOM negatif. }\end{array}$ \\
\hline \multicolumn{2}{|c|}{$\begin{array}{l}\text { Korespondensi: } \\
\text { Nama: Leonard Adrie Manafe } \\
\text { Email: leonard.adrie@stiemahardhika.ac.id }\end{array}$} \\
\hline
\end{tabular}


Strategi Word of Mouth Produk Sinom-Vac: Pembicara, Topik, Alat, Partisipasi dan Pengawasan

Kevin Reynaldi Bagaskara, Leonard Adrie Manafe, Viviana Sulistya Angraini, Mayrine Christiyah Nugrahini

\section{PENDAHULUAN}

Word of Mouth (WOM) merupakan salah satu teknik pemasaran yang lebih ditekankan pada peran konsumen dalam menggunakan anggota mulut sebagai sarana promosi atau komunikasi. Ditinjau dari segi pengeluaran/cost, penggunaan strategi WOM cederung relatif murah dan sangat besar efektivitasnya. Lagi pula masyarakat Indonesia yang cenderung suka tergabung dalam kumpulan, berbaur dan bersosialisasi diantara sesama komunitas mereka. Topik pembicaraan yang sering muncul diantara komunitas tersebut terkait banyak hal yang mereka gemari dan bersifat alami. Percakapan dari mulut ke mulut dalam rangka memperluas dan memperpanjang informasi yang hangat diantara masyarakat. Tentu saja, percakapan tersebut akan memberi pertajaman informasi yang berdampak pada keyakinan akan topik tertentu. Bahasa yang digunakan terbilang relatif sederhana da mudah dimengerti oleh kalangan komunitas mereka. Peran bahasa dan komunikasi dapat dikatakan memiliki keterkaitan erat dan saling menyempurnakan.

Kuswarno dalam Harjanto (2010) Onbee Marketing Research yang memiliki hubungan kerjasama dengan Majalah SWA menunjukan bahwa komunikasi WOM, topik yang dibicarakan kembali kepada pihak lain mempunyai efek dengan tingkat pengaruh sebesar $85 \%$. Tingginya tingkat pengaruh terkait WOM terbukti sangat signifikan. Karena itu, WOM digunakan oleh sebagian besar para pemasar sebagai salah satu teknik pemasaran yang handal dengan asumsi bahwa suatu informasi dapat diperoleh dari sumber terpercaya dan tidak memakan waktu lama. Rekomendasi yang diberikan oleh pihak terdekat seperti teman karib, keluarga inti dan profesional terkait dengan rujukan suatu produk dapat berjalan mulus dan lancar.

Brand produk sinom (minuman) yang diproduksi Sinom-Vac terkait dengan proses promosi dan pemasaran hampir sama dengan apa yang dilakukan oleh produk sejenis. Bedanya, hanya promosi dan pemasaran tidak dilakukan secara terbuka alias lebih bersifat personal. Sebagai contoh yang telah dilakukan Sinom-Vac yaitu menjalankan private viewing dan teknik pemasaran dari mulut ke mulut. Informasi terkait promosi dan pemasaran produk Sinom-Vac dilakukan berdasarkan database yang dipunyai melalui media whatsapp dan sedikit dilakukan melalui email. Berangkat dari private viewing tersebut maka brand image produk Sinom-Vac dapat terjaga sehingga dapat mempengaruhi kepuasan tersendiri dari konsumen atau pemakainya.

Menemukan talker yang tepat memang marupakan suatu kunci keberhasilan komunikasi WOM. Oleh karena itu, pemilihan talker jangan sampai keliru dan lemah karena dapat menimbulkan dampak yang buruk mengakibatkan proses WOM menjadi terhambat. Markom SinomVac sendiri digunakan sebagai talker dalam penelitian ini dengan memakai tools yang menarik perhatian sebagai alat pembantu pesan. Ditambah pula informasi rujukan untuk memikat konsumen berkunjung langsung ke toko atau tempat penjualan dan semata-mata ini dilakukan untuk menghindari buruknya WOM.

Penambahan pengaruh positif akibat penyebaran WOM yang begitu cepat oleh orang atau kelompok yang mempunyai jaringan atau relasi luas yang terjadi secara alami. WOM yang terjadi didalam kelompok itu sendiri dapat juga memiliki kualitas baik dalam penyebaran informasi. Dalam hal memberikan keyakinan kuat kepada konsumen maka WOM yang unik dan persuasif perlu diterapkan.

WOM mempunyai fungsi sebagai suatu alat komunikasi baik secara sadar ataupun tidak dapat membuat persepsi konsumen terkait merek atau produk tertentu. Keputusan pembelian konsumen dapat mungkin terjadi apabila suatu perusahaan berhasil menciptakan positifnya pengaruh WOM terkait barang dan jasa yang ditawarkan.

WOM marketing dapat diartikan sebagai suatu aktivitas pemasaran yang dilakukan secara lisan, tulisan atau memakai media elektronik oleh manusia atau orang per orang yang telah memiliki pengalaman dalam memakai produk dan jasa untuk menceritakan akan kualitas suatu produk dan jasa tersebut (Kotler \& Keller, 2009). Keunggulan besar yang dimiliki strategi WOM dapat berpengaruh terhadap pembentukan perilaku konsumen dalam melakukan pembelian suatu produk dan jasa. Rujukan produk dan jasa yang bersumber dari teman atau orang yang terpercaya lebih kuat pengaruhnya dibandingkan sumber komersial (iklan atau penjualan).

Umumnya WOM terjadi tidak dibuat-buat atau secara alami konsumen akan menceritakan suatu merek atau brand yang digunakan kepada pihak lain (Kotler \& Amstrong, 2012).

WOM positif agar dapat terjadi maka perlu diperhatikan beberapa hal terkait 5 (lima) $\mathrm{T}$ (Sernovitz, 2012) yaitu: 1) Talkers (pembicara), adalah komunitas yang terdiri atas sekelompok orang yang sangat antusias terkait dengan penyampain suatu pesan. Dalam hal ini, pembicara 
melakukan komunikasi mengenai suatu merek atau brand kepada informan agar dapat disampaikan kepada jaringannya dalam rangka berbagi ide yang menarik dan semata-mata untuk membantu jaringannya; 2) Topics (topik), berangkat dari talker yang gemar akan membicarakan sesuatu terkait pengalaman individunya. Misalnya sesuatu hal terkait penawaran suatu merek mengenai spesial diskon, produk baru, kepuasan terhadap pelayanan. Topik yang dibicarakan oleh talker harus memiliki karakter yang simple, mudah dibicarakan dan bersifat alami; 3) Tools (alat), terkait pada perlengkapan yang digunakan dengan tujuan untuk mempermudah konsumen dalam menjalankan praktek WOM. Alat itu bisa berupa tester atau brosur; 4) Taking Part (partisipasi), adanya dukungan dari orang lain yang terlibat dalam percakapan atau dialog sehingga proses WOM tetap berlanjut. Hal ini perlu peran aktif internal perusahaan yang terlibat langsung dialog terkait memberikan bantuan/respon yang baik dan cepat kepada calon konsumen sehingga WOM memiliki arah yang pasti dan berpotensi untuk berkembang sesuai dengan target sasarannya. 5) Tracking (pengawasan), agar suatu WOM positif dapat terjadi dengan lancar maka perlu dilakukan suatu tindakan dari perusahaan terkait dengan pengawasan proses WOM tersebut. Citra akan produk dan jasa dapat terjaga apabila pengawasan WOM tetap berlanjut.

Untuk membuat konsumen menjadi yakin dalam mengambil keputusan pembelian akan suatu produk dan jasa maka perlu dilakukan promosi yang baik dan berkualitas. Dengan melakukan promosi yang tepat akan berpengaruh terhadap kesadaran akan konsumen dalam memilih produk atau merek yang ditawarkan oleh perusahaan. Komunikasi promosi harus menjadi perhatian serius oleh perusahaan agar produk atau merek dapat tersampaikan dengan tepat sasaran kepada konsumen sebagai pengguna dan tujuan perusahaan dapat tercapai.

Promosi dapat diartikan sebagai suatu proses komunikasi marketing mix yang perlu diperhatikan oleh perusahaan terkait dengan pemasaran produk dan jasa (Ali Hasan, 2007). Adapun tujuan dalam melakukan aktivitas suatu promosi, diantaranya : 1) Suatu brand atau merek dapat diciptakan dan ditingkatkan pada sasaran atau target pasar yang tepat; 2) Preferensi brand atau merek ditujukan tepat pada sasaran pasarnya; 3) Angka penjualan perusahaan menjadi naik dan memiliki pangsa pasar yang jelas; 4) Kegiatan terkait pembelian kembali dari konsumen menjadi terlaksana; 5)
Pengenalan akan produk baru; 6) promosi akan menciptakan angka konsumen baru.

Dipandang perlu untuk menyajikan beberapa hasil dari penelitian terdahulu terkait dengan strategi pemasaran WOM antara lain: 1) Penelitian yang dilakukan oleh Kusrini (2021) yaitu melakukan penelitian dikalangan orang tua murid terkait promosi SDIT Alam Biruni. Hasil penelitian menunjukan strategi komunikasi WOM dapat digunakan sebagai upaya promosi dalam menyebarkan informasi penerimaan siswa baru. 2) Selanjutnya, penelitian oleh Lestari \& Erawati (2019) menunjukan hasil bahwa promosi WOM UGJ memang lebih efektif digunakan dibandingkan menggunakan media sosial karena respon dari lawan bicara dengan mudah ditangkap dibandingkan pesan satu arah melalui website. 3) Penelitian berikutnya dilakukan oleh Toruan (2018) terkait implementasi WOM yang digunakan sebagai strategi komunikasi pemasaran La Perla Plaza Senayan. Hasil penelitian menunjukan pentingnya proses komunikasi WOM disebarkan oleh marketing dan pengunjung Plaza Senayan dapat memberikan rujukan kepada keluarga, teman dan kerabat serta orang-orang yang suka berbelanja.

Dengan memperhatikan latar belakang dan teori yang mendukung dalam penelitian ini maka tujuan dilakukannya penelitian untuk untuk mengetahui pengaruh pentingnya strategi pemasaran WOM yang melibatkan beberapa hal (talkers, topics, tools, taking parts, tracking) agar strategi ini dapat menguntungkan dalam melakukan pemasaran produk Sinom-Vac

\section{METODE}

\section{Jenis dan Teknik Pengumpulan Data}

Tujuan ditentukan suatu metode dalam melakuan penelitian agar permasalahan akan suatu kebenaran dapat ditemukan, dikembangkan, dan diterapkan baik dalam teori maupun praktek. Penelitian ini memakai pendekatan kualitatif deskriptif dimana fenomena yang timbul atau terjadi saat ini dapat dideskripsikan kebenarannya dengan melakukan perbandingan akan kesamaan dan fenomena tertentu.

Metode deskriptif dapat diartikan sebagai metode untuk melakukan penelitian terhadap suatu kelompok manusia, obyek, kondisi, pemikiran yang tersistem atau kejadian yang terjadi pada kondisi saat ini (Andi Prastowo, 2011). Metode ini digunakan peneliti untuk mengetahui bagaimana proses implementasi strategi pemasaran WOM beserta dengan konsep teori yang 
mendukung terkait dengna pemasaran produk Sinom-Vac.

Proses awal penelitian yaitu dilakukannya penyebaran kuesioner dan wawancara langsung kepada informan terkait dengan topik penelitian.

\section{Populasi dan Sample}

Hasil penelitian yang sudah terkumpul terdapat 31 informan yang dapat penulis survey dengan alat bantu kuesioner, dari 31 informan terdiri dari $20(64,5 \%)$ perempuan dan $11(35,5 \%)$ laki-laki, umur dari para informan rata-rata lebih dari 20 tahun dan kurang dari 30 tahun dimana terdapat 2 (dua) informan berumur 13 tahun, dan 1 (satu) informan berumur 66 tahun, domisili para informan yang kami dapat terdapat 3 (tiga) wilayah yaitu Sidoarjo, Surabaya, dan Pasuruan dimana wilayah Sidoarjo lebih mendominasi.

\section{Definisi Operasional Variable}

Terdapat 5 (lima) elemen komunikasi WOM yaitu :

Talkers, yang menjadi pembicara dalam penelitian ini adalah konsumen yang melakukan pembelian produk Sinom-Vac. Tentu saja konsumen ini memiliki pengalaman mengenai penggunakan produk Sinom-Vac. Karena adanya pengalaman tersebut pembicara mempunyai pengaruh kuat dan kepercayaan untuk melakukan rekomendasi atau referensi produk kepada pihak lain. Disamping itu, peran Markom produk SinomVac memiliki pengaruh kuat dan terpercaya terhadap kelangsungan proses WOM. Seorang pembicara diharapkan mempunyai kepercayaan dan kredibilitas yang tinggi, kuatnya pengaruh seorang pembicara dalam menyampaikan pesan yang mudah dan jelas dimengerti oleh konsumen lainnya serta seorang pembicara harus mempunyai pengetahuan yang mendalam terkait produk yang direferensikan. Seorang pembicara yang berkredibilitas ditopang dengan keterampilan dalam melakukan komunikasi baik secara lisan maupun tertulis dan luasnya pengetahuan akan produk yang dibahasnya.

Topics, WOM dapat terjadi apabila terciptanya suatu topik atau pesan/perihal yang dibicarakan oleh informan terkait produk dan jasa yang digunakan. Pembicaraan topik mengenai kualitas pelayanan, berita atau informasi terkait produk dan jasa yang disajikan. Seorang pembicara harus mempunyai kemampuan atau berkapasitas tinggi untuk menghasilkan/create topik yang tepat dan menarik. Pemahaman terhadap topik harus mendalam dan tidak hanya berhenti disitu tetapi seorang pembicara harus memiliki kemampuan dalam melakukan percakapan yang tinggi agar dapat mempengaruhi atau membujuk konsumen untuk melakukan pembelian produk dan jasa dan dari hasil percakapan tersebut harus mendapatkan feedback positif.

Tools, setelah informan yang memiliki kemampuan yang tinggi mampu membahas topik maka perlu dipikirkan untuk membuat alat agar dapat membantu proses supaya pesan terkait topik tersebut dapat tersampaikan dengan baik dan lancar kepada konsumen lainnya. Alat bantu tersebut bisa berupa pemberian souvenir, mini gift atau alat bantu simple lainnya. Dengan adanya alat bantu tersebut pembicaraan terkait topik produk dapat ditularkan dengan cepat kepada teman informan.

Taking Part, sebagai tindak lanjut atau follow up terhadap calon konsumen maka perlu adanya tanggapan yang cepat terkait adanya pertanyaan konsumen dengan jelas dan detail. Pertanyaan konsumen terkait produk yang ditawarkan, harga yang diberikan, diskon harga yang dipromosikan perlu ditanggapi dengan cepat supaya konsumen dengan cepat mengambil keputusan untuk melakukan pembelian produk dan jasa yang ditawarkan. Selain itu perlu diperhatikan dalam pembuatan kotak saran untuk menampung respon konsumen baik yang berpendapat positif atau negatif yang nantinya dapat dijadikan bahan evaluasi untuk perbaikan kualitas produk dan jasa.

Setelah memperhatikan elemen tersebut diatas, tidak terlepas dengan hambatan atau kendala yang terjadi dilapangan. Tentu saja secara langsung ataupun tidak langsung akan mempengaruhi pencapaian target perusahaan. Beberapa contoh hambatan yang sering terjadi didalam perusahaan seperti tenaga marketing atau penjualan yang kurang ramah, susah senyum dalam memberikan pelayanan dan pihak perusahaan yang kurang peka apa yang menjadi selera konsumen. Sedangkan hambatan luar perusahaan dapat berupa munculnya pandangan negatif terkait isu WOM dari konsumen.

Teori interaksi simbolik yang digunakan dalam penelitian ini dalam menerapkan strategi WOM. Teori interaksi simbolik menjelaskan bahwa pentingnya penggunaan simbol dalam berinteraksi sosial. Jika terjadi percakapan diantara dua orang maka dapat dikatakan percakapan tersebut bersifat komunikatif. Adanya pemahaman yang jelas terkait topic yang dibicarakan. Dapat ditarik intinya bahwa lapisan masyarakat bukan variabel atau faktor yang menentukan perilaku manusia melainkan interaksi sosial dipandang sebagai faktor atau hal penting dalam menentukan perilaku 
manusia. Dengan adanya kegiatan komunikasi dalam bentuk percakapan yang terjadi dengan pihak lain maka akan berdampak terhadap pemahaman yang lebih baik lagi terkait masalah diri sendiri. Pesan yang diterima dan dikirim akan lebih bermakna untuk diri sendiri maupun orang lain.

\section{HASIL PENELITIAN DAN PEMBAHASAN}

Berdasarkan pengumpulan dan analisa data, penulis mendapat 31 informan, diantaranya 20 informan perempuan dan 11 informan laki-laki. hasil interpretasi penelitian ini berdasarkan kuisioner yang kami bagikan dan wawancara langsung dengan informan.

Pada pembahasan ini penulis akan membahas mengenai WOM oleh produk sinom Sinom-vac dengan teori 5T's Talkers, Topics, Tools, Taking part, Tracking.

\section{Talkers}

Dalam penelitian, penulis menyimpulkan bahwa talkers pada produk Sinom-Vac adalah para konsumen yang telah membeli produk Sinom-Vac, dimana lebih dari $90 \%$ informan secara langsung mempromosikan produk Sinom-Vac dengan bercerita ke orang terdekat informan seperti teman, tetangga, keluarga. Dan kebanyakan yang informan ceritakan tentang rasa yang unik dan lebih segar dari produk Sinom-Vac, cara pembuatan produk Sinom-Vac yang menggunakan bahan-bahan tradisional dan kealamian rempah-rempah yang memiliki kualitas baik menjadi pokok pembicaraan para talkers.

Kepiawaian informan yang didominasi perempuan dibuktikan dengan banyak diantara informan yang bergabung dalam komunitas arisan, perkumpulan organisasi mahasiswa, jaringan media sosial yang luas. Banyak diantara informan yang piawai dalam berbicara sehingga kualitas WOM dapat dirasakan dan berjalan efektif.

Keberlanjutan bisnis Sinom-Vac akan semakin nyata dan tujuan perusahaan akan semakin tercapai apabila rujukan akan produk Sinom-Vac semakin gencar dilakukan oleh konsumen.

\section{Topics}

Dalam kuisioner yang telah di bagikan, topics yang di bahas adalah tentang cara mempromosikan dan respon dari responden. Cara informan mempromosikan dengan social media (whatsapp, instagram, facebook, dan twitter), face to face (secara langsung, menceritakan ke tetangga, teman, keluarga), tentang rasa (segar, manis, dan enak), dan manfaat (melancarkan pencernaan, bagus untuk program diet, menyegarkan tubuh, membantu proses detoksifikasi, meredakan nyeri berkat flavonoid, melancarkan peredaran darah, mengatasi radang lambung dan sakit maag). Dimana cara mempromosikan dengan menceritakan tentang rasa yang enak dan segar menjadi yang paling banyak dengan 12 informan. Respon dari responden, informan penasaran, tertarik, dan suka dengan produk Sinom-Vac. Ada bertanya "enak ta?", banyak responden yang tertarik dengan Sinom-Vac dengan 16 suara dan 8 (delapan) suara responden penasaran dan 7 (tujuh) suara responden suka. Dari pengamatan penulis terhadap hasil wawancara yang dilakukan banyak informan yang memberikan informasi terkait tanggapan atas topik yang dibicarakan sangat antusias dan menarik lawan bicara. Banyak diantara calon konsumen merasa penasaran dan ingin cepat membeli produk Sinom-Vac untuk membuktikan kualitas produk yang diceritakan.

Loyalitas pelanggan atau konsumen terjadi karena adanya kepercayaan konsumen terhadap produk Sinom-Vac. Dasar atau inti utama dalam menjalankan strategi pemasaran yang tepat adalah unsur kepercayaan konsumen. Produk yang dihasilkan Sinom-Vac berupa sinom saat ini mendapat rujukan dan referensi dari konsumen. Itu menandakan bahwa konsumen menaruh kepercayaan akan kualitas produk Sinom-Vac dan secara tidak langsung kepercayaan calon konsumen baru dapat ditanamkan juga.

\section{Tools}

Berdasarkan hasil kuisioner dan wawancara, tools yang digunakan pada produk Sinom-Vac adalah tester produk. Dari seluruh jawaban informan, informan menjawab tester produk Sinom-Vac menarik bahkan 12 (38,7\%) informan menjawab sangat menarik. Dan dari hasil promosi tersebut informan menyaran kan agar memberi varian rasa (sinom susu, sinom boba, sinom cincau), porsi bertambah banyak untuk tester, kualitas yang sangat terjaga dengan baik, dan kemasan yang unik dan berbeda dengan yang lain yaitu kemasan berbentuk segitiga dimana kemasan lain kebanyakan berbentuk kotak dan bulat. Banyak dari usulan informan menginginkan tester dengan porsi yang lebih banyak dan variatif dengan menggunakan media sosial.

Orang banyak tertarik untuk mencoba produk dan jasa yang ditawarkan. Informan akan mendorong untuk memberikan rekomendasi atau referensi kepada orang lain mengenai suatu produk, hal ini dapat terjadi pada saat informan mengalami dan merasa puas akan hasil dan kualitas suatu produk. Media website dan akun 
sosial media akan digunakan sebagai platform komunikasi penjualan produk. Melalui cara demikian, produk Sinom-Vac akan memperoleh masukan positif dan berharga dan tentu saja akan bermanfaat untuk peningkatan kualitas produk dan pelayanan.

Disamping itu, kenyamanan dan kepuasan konsumen semakin terasa karena penerapan kualitas pelayanan Sinom-Vac. Pelanggan diikutsertakan dalam kegiatan promosi melalui media sosial dengan mengundang atau mengajak informan untuk tampil dalam setiap pengambilan foto dan video yang akan diunggah di media sosial. Brand Sinom-Vac akan semakin terkenal dan populer dan sekaligus kegiatan ini juga dapat mempererat hubungan diantara bisnis Sinom-Vac dan pelanggan.

\section{Taking Part}

Dalam meningkatkan jumlah konsumen Sinom-Vac secara tidak langsung melibatkan konsumen dengan cara memberikan pelayanan yang maksimal dan menjadikan konsumen seperti teman informan sendiri. Hal ini tentu sangat berpengaruh kepada konsumen agar membeli produk Sinom-Vac lagi. Dari hasil kuesioner dan wawancara dengan informan, informan senang dengan pelayanan Sinom-Vac yang baik, bahkan 18 $(58,1 \%)$ informan menjawab pelayanan sangat baik dan $13(41,9 \%)$ informan menjawab pelayanan baik. Penyampaian terkait khasiat dari produk Sinom-Vac yang dapat menyegarkan tubuh, melancarkan peredaran darah, dan mengatasi radang lambung dan sakit maag, hampir semua informan menjawab sudah, hanya 2 (6,5\%) informan saja yang belum mendapat informasi khasiatnya dikarenakan kelalaian dari tim pemasaran yang tidak fokus bekerja. Sehingga dari apa yang dijelaskan ke informan tentang khasiat dari produk Sinom-Vac membuat informan semakin tertarik, dan penasaran apalagi khasiat dari produk Sinom-Vac yang mengandung bahan alami dari rempah-rempah murni berasal dari Indonesia diperoleh langsung dari sumbernya. Produk Sinom-Vac juga tidak menggunakan bahan pengawet dimana masa expired produk Sinom-Vac hanya bertahan selama 7 (tujuh) hari dalam suhu dingin dan 3 (tiga) hari dalam suhu panas, tidak adanya bahan kimia membuat produk Sinom-Vac terasa lebih alami.

\section{Tracking}

Dari hasil kuesioner dan wawancara, tracking dilakukan sudah berjalan cukup baik sehingga kualitas dan keutuhan produk Sinom-Vac sangat terjaga. Dengan tidak ditemukan kecacatan produk selama produksi dan proses jual beli, hanya 1 $(3,2 \%)$ informan yang pernah menemukan kecacatan pada kemasan produk Sinom-Vac. Dengan begitu diharapkan akan lebih teliti dalam produksi, sehingga tidak terulangnya kecacatan pada produk Sinom-Vac kembali. Tracking yang dilakukan mengacu pada meminimalisir sebuah berita negatif pada produk Sinom-Vac, cara yang dilakukan sedikit sederhana yaitu dengan membuat konsumen menjadi kolega bisnis. Perusahaan memberikan sedikit bonus pada konsumen sehingga hubungan antara penjual dan pembeli menjadi lebih dekat dan secara tidak langsung informan akan membela produk SinomVac jika terdapat kompetitor yang berbuat jahat pada produk Sinom-Vac. Jika ditemukan kecacatan pada produk Sinom-Vac maka pembeli akan mendapat garansi dengan penggantian produk yang baru dan bonus 1 (satu) botol atas permintaan maaf.

\section{Pengaruh Dominan Indikator 5T}

Dari hasil penelitian, dari indikator 5T's Talkers, Topics, Tools, Taking part, dan Tracking, para informan lebih dominan memilih Tools sebagai alasan kenapa informan tertarik dengan produk Sinom-Vac. Karena di rasa lebih efisien dimana informan mendengar cerita positif tentang produk Sinom-Vac dan terlebih lagi ada tester yang membuat para konsumen menjadi lebih percaya dengan apa yang diceritakan oleh informan. Strategi WOM yang diterapkan mempermudah untuk pemasaran produk Sinom-Vac, dan membuat kesan yang menarik sehingga membuat para pembeli teringat akan produk Sinom-Vac, untuk calon konsumen informan akan lebih mengenal produk Sinom-Vac tanpa melihat dan mengetahui rasa dari produk Sinom-Vac yang hanya dengan mendengar dari cerita dari luar.

Selain itu, tetap menjaga dan berusaha menciptakan strategi WOM dengan: 1) Memberikan pengetahuan tentang khasiat dari produk Sinom-Vac. 2) Memberi penghargaan pada konsumen dengan memberi bonus tester sehingga meyakinkan informan untuk membeli. 3) Membuat pesan yang membuat para kosumen dan calon konsumen mengingat produk Sinom-Vac 4) Membuat pelayanan semaksimal mungkin sehingga informan merasa lebih di hargai, bukan hanya sekedar penjual dan pembeli

Produk Sinom-vac memiliki ciri khas tersendiri sehingga keunikan ini memudahkan konsumen maupun calon konsumen mengenali dan mengingatnya. Dalam konteks ini keunikan yang produk Sinom-Vac tunjukan berada pada 
kemasan yang berbentuk segitiga, dimana mayoritas kemasan produk sinom berbentuk persegi dan bulat.

\section{KESIMPULAN DAN SARAN}

Proses strategi WOM pada produk Sinom-Vac yang disebarkan oleh penjual dan konsumen yang memberikan rujukan atau referensi kepada sahabat dekat, kerabat keluarga, konsumen pecinta minuman yang terbuat dari bahan herbal, serta penyebaran kuesioner dan wawancara langsung diperoleh bahwa dalam perancangan strategi Sinom-Vac dengan menggandeng konsumen dengan menganggap sebagai teman sendiri.

Indikator pada produk Sinom-Vac, yaitu talker yang merupakan konsumen Sinom-Vac sendiri. Topic berhubungan dengan tambahan pemahaman akan suatu produk untuk para konsumen, yang berakhir dimana informan akan melakukan pembicaraan kembali terkait produk kepada partnernya. Diberikannya tester sebagai tools untuk pembuktian kualitas produk yang ditawarkan, setelah itu pemberian pelayanan kunjungan yang prima dilakukan secara langsung atau tidak langsung merupakan bagian dari taking part, dan langkah berikutnya masuk dalam tahap tracking pihak Sinom-Vac memberikan respon dengan membalas keluhan pelanggan dengan cepat untuk mengurangi WOM negatif.

Hambatan-hambatan WOM produk SinomVac adalah kurangnya varian rasa dan ukuran produk Sinom-Vac. Berdasarkan simpulan yang diperoleh, maka disarankan kepada perusahaan agar lebih kreatif dan bervariatif dalam membuat produk sehingga ada pembanding dan lebih menarik minat konsumen.

Penelitian ini telah menunjukan bahwa produk Sinom-Vac perlu melakukan inovasi dan lebih memperhatikan apa yang menjadi kemauan konsumen.

Hasil penelitian ini memberikan beberapa implikasi 1) Implikasi terhadap cara mempromosikan secara tidak langsung, 2) Implikasi terhadap respon dari responden yang memiliki ketertarikan, meskipun belum mengetahui produk Sinom-Vac. 3) Implikasi terhadap saran promosi yang membuat calon konsumen tertarik pada produk Sinom-Vac. 4) Implikasi terhadap bagaimana cara memberikan pelayanan yang layak kepada konsumen. 5) Implikasi terhadap bagaimana cara mempertahankan produk agar tidak terjadinya negative campaign.

Untuk penelitian selanjutnya penulis berharap peneliti selanjutnya akan melakukan hal berikut : lebih memperluas survey dimana hasil survey penulis peroleh rata-rata informan dalam penelitian ini berusia 30 tahun kebawah. Untuk target selanjutnya penulis berharap akan adanya penelitan yang lebih tertuju pada informan berusia 30 ke atas, terutama kepada para informan yang suka berolahraga. sehingga penelitian bisa mendapat lebih banyak informasi tentang apakah para konsumen saat kelelahan setelah berolahraga meminum minuman herbal (sinom) dan juga lebih memudahkan untuk promosi dengan metode WOM.

Penelitian selanjutnya tetap menggunakan konsep penelitian yang serupa tetapi obyek yang berbeda. Konsep yang digunakan dalam penelitian ini sangat terbantukan untuk perusahaan yang ingin menerapkan strategi pemasaran WOM. Untuk bagian teori WOM 5T's perlu digali lagi disebabkan karena masih jarang peneliti serupa menggunakan konsep teori ini dan terdapat beberapa poin pembahasan dari penulis memiliki kecenderungan yang serupa dengan penelitian lainnya.

Adanya sosial media yang seharusnya lebih dimanfatkan untuk strategi promosi. Karena sosial media lebih meluas dalam melakukan promosi dan tanpa batas. Dimana juga di era sekarang semua serba teknologi dan musim pandemi banyak berbelanja melalui online.

\section{DAFTAR PUSTAKA}

A. Devito, Joseph. 2011. Komunikasi Antarmanusia. Tangerang Selatan: Karisma Publishing GroupA. Shimp, Terence. 2007. Periklanan Promosi (Aspek Tambahan Komunikasi Pemasaran Terpadu).. Jilid I, edisi Terjemahan, Jakarta: Erlangga

Ali, Hasan, 2007. Marketing. Yogyakarta: Media Pressindo. Alma, Buchari. 2009. Manajemen Pemasaran dan Pemasaran Jasa. Bandung: Alfabeta

Andi Prastowo. 2011. Metode Penelitian Kualitatif dalam Perspektif Rancangan Penelitian. Jogjakarta: Ar-Ruzz Media

Devito, Joseph A. 2011. Komunikasi Antar Manusia. Jakarta: Karisma Publishing Group

Gurnelius, Susan. 2011. 30-minute Sosial Media Marketing, United States: McGraw-Hill Companies.

Harjanto. 2010. Onbee marketing reseacrh. Jakarta: majalah SWA 
Strategi Word of Mouth Produk Sinom-Vac: Pembicara, Topik, Alat, Partisipasi dan Pengawasan Kevin Reynaldi Bagaskara, Leonard Adrie Manafe, Viviana Sulistya Angraini, Mayrine Christiyah Nugrahini

Kotler \& Keller. 2009. Manajemen Pemasaran. Jilid I, Edisi ke 13. Jakarta: Penerbit Erlangga.

Kotler \& Amsstrong. 2012. Manajemen Pemasaran, Jilid I dan II. Jakarta: PT. Indeks.

Kusrini. 2021. Strategi Komunikasi Word of Mouth (WOM) Sebagai Upaya Promosi SDIT Alami Biruni. Studi Komunika, Jurnal Ilmu Komunikasi. Vol. 4 No. 1 (28-32)

Lestari \& Erawati. 2019. Proses Word of Mouth Communications Sebagai Media Promosi Universitas Swadaya Gunung Jati Cirebon. Jurnal Signal. Vol. 7 No. 2 (224-239)

Marius P,Angipora. 2002. Dasar-Dasar Pemasaran. Jakarta: PT. Raja Grafindo Persada.

Moleong, J, Lexy. 2006. Metodologi Penelitian Kualitatif. Bandung: PT. Remaja Rosdakarya.Gramedia.

Peter J. Paul \& Donnelly, James H. 2011. Marketing Management, Knowledge and Skill, Tenth Edition. New York: Mc Graw Hill.
Rakhmat, Jalaludin. 2007. Psikologi Komunikasi, bandung: Remaja Rosdakarya.

Rusady, Ruslan. 2004. Public Relation, Edisi Revisi ke-2. Jakarta: PT. Raja Grafindo Persada.

Sermovitz, Andi. 2012. Word of Mouth. New York: Kaplan

Solis, Brian. 2010. Engage: The Complete Guide for Brands and Business to Build, Cultivate, and Measure Success in the New Web. New Jersey: John Wiley \& Sons Inc.

Sugiyono, 2005. Metode Penelitian Administrasi. Bandung: Alpabeta

Toruan, Rialdo. 2018. Proses Implementasi Word of Mouth Dalam Strategi Komunikasi Pemasaran La Perla Plaza Senayan. Jurnal Pustaka Komunikasi. Vol. 1 No. 1 (155-166). 